\title{
DESENTISISASI OBAT
}

\author{
Selly Cintya Gusman ${ }^{1)}$, Raveinal ${ }^{2}$ \\ ${ }^{1}$ Fakultas Kedokteran, Universitas Andalas, Bagian Penyakit Dalam RSUP M. Djamil Padang \\ email:scgusman@gmail.com \\ ${ }^{2}$ Fak ultas Kedokteran, Universitas Andalas, Bagian Penyakit Dalam, Divisi Alergi Imunologi \\ RSUP M. Djamil Padang. email : raveinal.pdg@ yahoo.co.id
}

\section{Submitted: 20-05-2020, Reviewer: 12-05-2020, Accepted: 08-05-2020 \\ Abstract}

Giving drugs to some patients has the potential to experience side effects that can be life-threatening so doctors must provide alternative medicine to them. If the suspect's drug is not replaced by alternative medicine, drug desensitization can be carried out. Drug desensitization is a temporary induction of a state of tolerance to the drug. Although this therapy is only empirical, it is effective and with a better understanding of the mechanism of desensitization is expected to improve therapeutic methods. Considerations for determining desensitization protocols do not have to be rigid, they should follow a number of steps, namely patient evaluation aimed at finding the characteristics of adverse reactions in patients, determining the possibility of effective and safe fast drug desensitization, selecting appropriate protocols, gathering information about the patient's response to desensitization, and change the protocol as needed. Desensitization is said to be successful if the patient can complete up to the therapeutic dose and can tolerate repeated dosing until treatment is complete.

Keywords: desensitization, desensitization algorithm, adverse drug reaction

\begin{abstract}
Abstrak
Pemberian obat pada beberapa pasien berpotensi mengalami efek samping obat yang dapat mengancam jiwa sehingga dokter harus memberikan obat alternatif terhadap mereka. Jika obat tersangka tidak tergantikan dengan obat alternatif, dapat dilakukan desensitisasi obat. Desensitisasi obat adalah induksi sementara keadaan toleransi terhadap obat. Meskipun terapi ini hanya bersifat empiris, tetapi efektif dan dengan pemahaman yang lebih baik terhadap mekanisme desensitisasi diharapkan dapat meningkatkan metode terapi. Pertimbangan un tuk menentukan protokol desensitisasi tidak harus kaku, sebaiknya men gikuti beberapa langkah, yaitu evaluasi pasien yang bertujuan untuk mencari karakteristik reaksi simpang pada pasien, menentukan kemungkinan desensitisasi obat cepat yang efektif dan aman, memilih protokol yang tepat, men gumpulkan informasi me genai respons pasien terhadap desensitisasi, dan meng ubah protokol sesuai yang diperlukan. Desen sitisasi dikatakan sukses jika pasien dapat menyelesaikan sampai dengan dosis terapeutik dan dapat mentoleransi pemberian dosis berulang sampai pengobatan selesai.
\end{abstract}

Kata kunci: desentisisasi, algoritma desentisasi, reaksi simpang obat

\section{PENDAHULUAN}

Berbagai jenis penyakit melahirkan penemuan sejumlah besar agen farmakologis. Dari sejumlah besar obat yang tersedia, dokter harus menentukan yang paling tepat untuk setiap pasien. Beberapa pasien berpotensi mengalami efek samping obat yang dapat mengancam jiwa sehingga dokter harus memberikan obat alternatif terhadap mereka. Namun, pada keadaan tertentu obat sangat esensial untuk kasus tertentu sehingga tidak dapat diganti dengan obat lain. (1), (2)

Reaksi simpang obat dapat terjadi pada $10-20 \%$ pasien rawat dan lebih dari $7 \%$ populasi umum. Reaksi simpang obat dibedakan menjadi tipe A (farmakologi/ toksik) dan tipe B (hipersensitivitas). 
Manifestasi penyakit pada tipe A dapat diprediksi, bergantung pada dosis obat, efek toksik dari obat pada dosis yang disarankan atau dosis yang berlebihan. Tipe B memiliki manifestasi klinis yang tidak dapat diduga dan berbeda tiap individu. Gejala terjadi dalam satu hingga enam jam setelah meminum obat atau beberapa jam hingga hari dengan gejala yang muncul bisa ringan (bersin) hingga berat (anafilaksis). (3)

Reaksi hipersensitivitas obat termasuk dalam reaksi simpang obat tipe B, mewakili sekitar sepertiga dari semua reaksi simpang obat. Menurut World Health Organization (WHO), alergi obat diartikan sebagai reaksi hipersensitivitas yang ditandai oleh reaksi imunologi, yang diperantarai $\mathrm{IgE}$ atau sel $\mathrm{T}$, dan terkadang oleh kompleks imun atau reaksi sitotoksik. (4)

Salah satu tatalaksana alergi obat adalah menghindari obat tersangka. Jika obat tersangka tidak tergantikan dengan obat alternatif, dapat dilakukan desensitisasi obat. (5) Mekanisme dari desensitisasi masih tidak pasti, tetapi hal ini spesifik secara imunologi terhadap alergen yang diinjeksikan. Respon imunologi spesifik yang bermacam-macam diinduksi selama terapi desensitisasi. (6) Perbaikan klinis selama desensitisasi lebih disebabkan karena penghambatan terhadap respon antibodi dari pada perubahan imunologi yang lain, akan tetapi terapi kombinasi dari beberapa mekanisme mungkin dibutuhkan untuk mendapatkan hasil yang lebih optimal. (7)

Desentisisasi obat merupakan tatalaksana alergi obat bila obat tersangka tidak tergantikan. Kesuksesan maupun kegagalan desensitisasi tergantung pada banyak variabel, termasuk potensi dari ekstrak yang digunakan untuk desensitisasi, dosis dari ekstrak, dan penyakit yang diderita. Meskipun terapi ini hanya bersifat empiris tetapi efektif, dan dengan pemahaman yang lebih baik terhadap mekanisme desensitisasi diharapkan dapat meningkatkan metode terapi. ${ }^{(7)}$

\section{DEFINISI}

Desensitisasi obat adalah induksi sementara keadaan toleransi terhadap obat. Desensitisasi obat dapat melibatkan mekanisme imunologik yang diperantarai IgE, mekanisme imunologik non-IgE, mekanisme farmakologis, dan mekanisme yang tidak terdefinisi. Desensitisasi obat merupakan bagian dari induksi toleransi obat, dimana sel efektor menjadi kurang atau tidak responsif terhadap respons imun yang diperantarai IgE. Berdasarkan literatur, hasil desensitisasi obat akan lebih baik pada individu yang mengalami reaksi hipersensitivitas dalam waktu 24 jam setelah minum obat. ${ }^{(8)}$

Desensitisasi cepat ditujukan untuk obat yang menimbulkan reaksi hipersensitivitas yang diperantarai IgE. Prosedur ini berlangsung sangat cepat, dosis terapeutik tercapai dalam waktu 4 sampai dengan 12 jam. Prinsip umum protokol ini adalah menaikkan dosis secara progresif dalam waktu beberapa jam, dimulai dengan dosis obat yang sangat kecil kemudian menggandakan dosis setiap 15 menit dan diamati selama 2 jam setelah dosis obat terakhir. Beberapa pasien memerlukan dosis awal yang lebih rendah dengan rentang yang lebih lama di antara waktu pemberian dosis. (2)

Protokol desensitisasi pada hipersensitivitas tidak diperantarai $\mathrm{IgE}$ disebut sebagai desensitisasi lambat. Peningkatan dosis secara bertahap menimbulkan adaptasi terhadap metabolit reaktif obat. Prinsip dari protokol ini adalah obat diberikan dengan dosis rendah kemudian dinaikkan dalam waktu 1-2 jam atau lebih untuk mencapai dosis terapeutik. Hampir $15 \%$ pasien memerlukan interval pemberian dosis obat lebih lama sehingga dosis terapeutik tidak akan tercapai dalam waktu 1-2 minggu. (9) 
INDIKASI DAN KONTRAINDIKASI

Desensitisasi obat diindikasikan pada keadaan obat tidak tergantikan dan keuntungan melebihi kerugian yang mungkin terjadi. Desensitisasi dapat dilakukan jika suatu obat dinilai lebih efektif dibandingkan obat alternatif dan obat memiliki mekanisme kerja yang khas. ${ }^{(2)}$

Desensitisasi tipe cepat ditujukan untuk pasien yang sudah terbukti atau diduga kuat memiliki antibodi IgE spesifik terhadap obat tersangka. Meskipun demikian, saat ini desensitisasi obat telah digunakan untuk induksi toleransi pada reaksi alergi yang tidak diperantarai IgE, misalnya pada reaksi alergi tipe lambat seperti fixed drug eruption dan erupsi makulopapular. (10)

Desensitisasi terhadap obat tersangka tidak boleh dilakukan pada pasien berisiko tinggi, yaitu pasien dengan komorbiditas, misalnya pasien asma tidak terkontrol dengan nilai FEV1 $<70 \%$ dari nilai normal, pasien dengan hemodinamik yang tidak stabil atau penyakit jantung tidak terkontrol. Kontraindikasi absolut adalah riwayat reaksi alergi obat yang parah dan mengancam jiwa, vaskulitits, sindrom Stevens-Johnson (SSJ) atau toxic epidermal necrolysis (TEN), dan sindrom hipersensitivitas obat, sedangkan reaksi anafilaksis bukan merupakan kontraindikas i. (2)

\section{MEKANISME DESENTISISASI OBAT}

Mekanisme desensitisasi masih belum diketahui dengan baik terutama pada reaksi alergi yang tidak diperantarai IgE. Sel mast dan basofil diduga menjadi target utama karena mediator dari sel ini dilepaskan selama reaksi hipersensitivitas obat dan juga selama prosedur desensitisasi. Beberapa mekanisme yang diduga mendasari proses desensitisasi tipe cepat adalah 1) internalisasi antigen/IgE/FCERI dan inhibisi reseptor sel mast, 2) molekul sinyal transduksi seperti Syk kinase yang diperlukan untuk aktivasi sel mast berkurang, 3) deplesi mediator di bawah ambang. (11)

Beberapa peneliti membuktikan pemberian dosis suboptimal mengakibatkan sel mast menjadi tidak responsif terhadap obat yang diberikan. Penjelasan yang mungkin tepat adalah pemberian dosis suboptimal secara bertahap memberikan jumlah antigen yang cukup untuk berikatan dengan satu IgE yang telah berikatan reseptor FcERI, namun tidak berikatan silang dengan dua IgE (Gambar 1). ${ }^{(12)}$

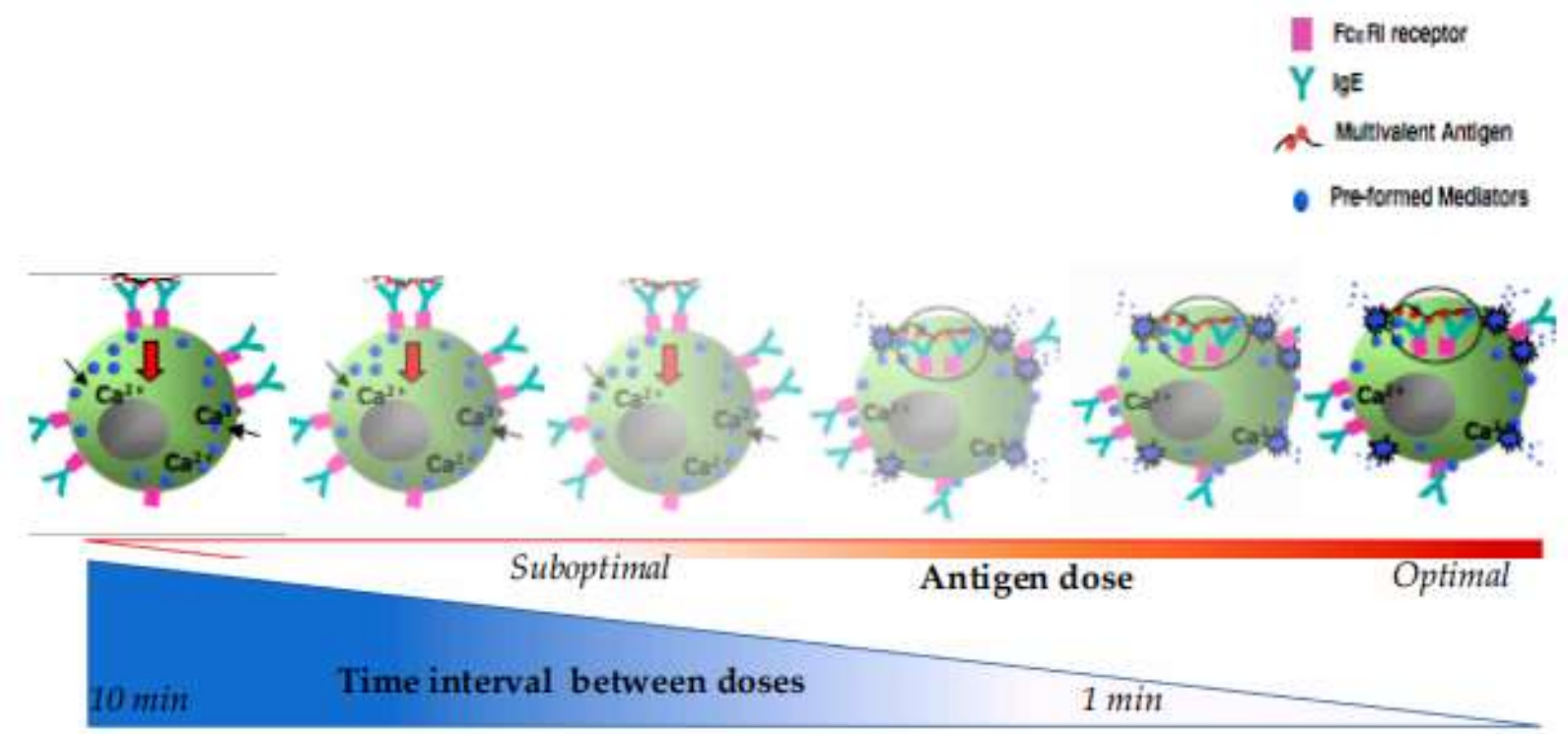




\section{Gambar 1. $\beta$-hexosaminidase sel mast berhubungan dengan interval wak tu antar dosis dan dosis} antigen selama desentisisasi ${ }^{(12)}$

\section{TATA CARA DESENTISISASI OBAT \\ Tata Cara Umum}

Sebelum memulai prosedur desensitisasi dokter harus menelaah risiko dan keuntungan tindakan tersebut (Gambar 2). Karena berisiko terjadi reaksi hipersensitivitas akut, desensitisasi harus dilakukan dibawah pemantauan dokter dan perawat yang sudah terbiasa dan memahami prosedur tersebut serta penatalaksanaan reaksi anafilaksis dengan benar. Prosedur desensitisasi harus dilengkapi peralatan dan obat-obatan untuk tatalaksana reaksi alergi serta resusitasi jantung-paru. Untuk menambah keamanan, pasien harus diberitahu gejala dan tanda awal reaksi anafilaksis dan ia harus segera memberitahu perawat atau dokter jika terjadi gejala dan tanda reaksi. Saat ini masih ada perdebatan apakah prosedur desensitisasi harus dikerjakan di unit perawatan intensif. Banyak pusat yang sudah berpengalaman melakukan desensitisasi di poliklinik. Pada beberapa kasus, pasien yang telah menyelesaikan prosedur pertama dengan gejala minimal atau tidak ada gejala, dapat melanjutkan prosedur kedua dan seterusnya di poliklilnik. (2)

Pertimbangan untuk menentukan protokol desensitisasi tidak harus kaku. Penentuan protokol desensitiasi sebaiknya mengikuti beberapa langkah, yaitu evaluasi pasien yang bertujuan untuk mencari karakteristik reaksi simpang pada pasien, menentukan kemungkinan desensitisasi obat cepat yang efektif dan aman, memilih protokol yang tepat, mengumpulkan informasi megenai respons pasien terhadap desensitisasi, dan mengubah protokol sesuai yang diperlukan. Perubahan yang dapat dilakukan adalah menambah, mengurangi, atau mengubah premedikasi, mengubah jumlah tahapan dalam protokol, mengubah kecepatan atau waktu setiap tahapan, atau mengombinasi ketiganya. (2)

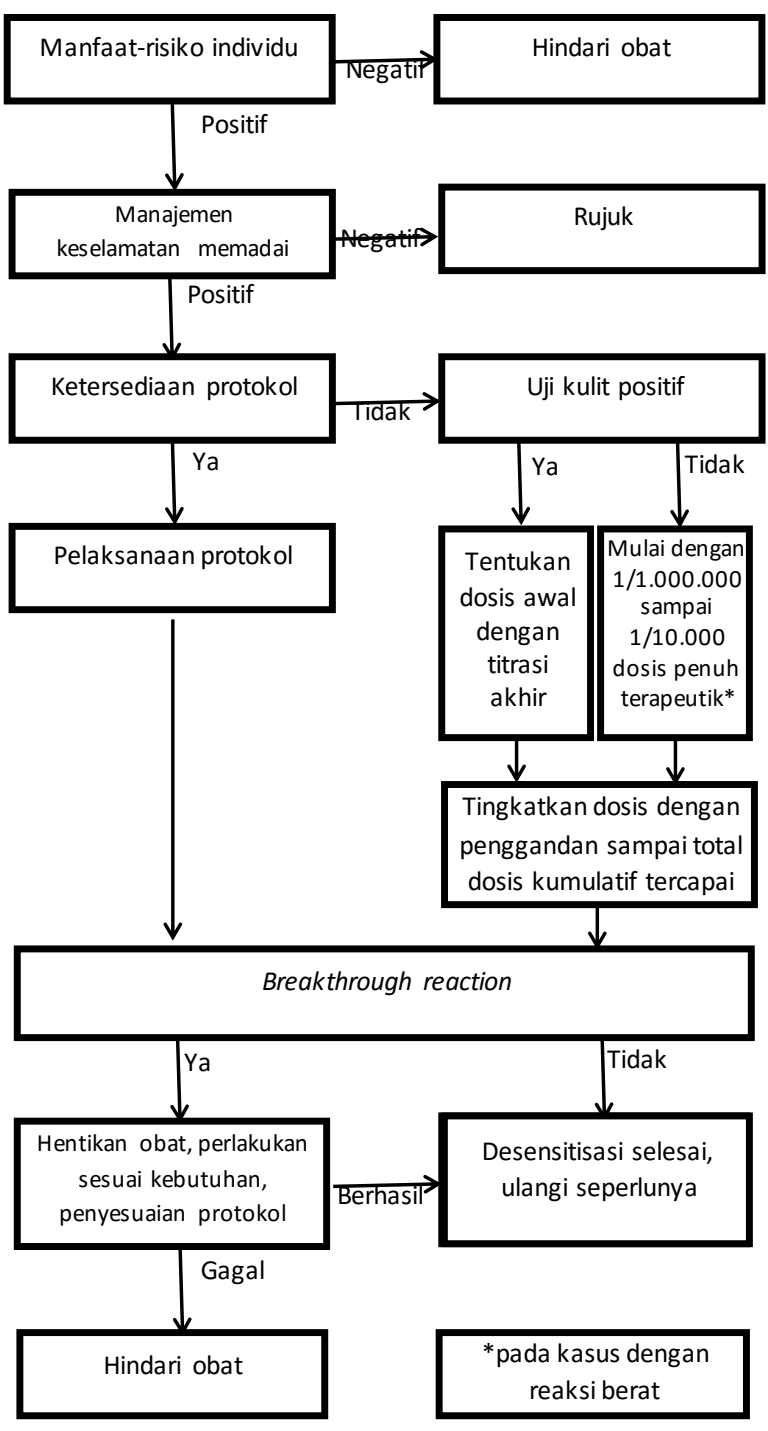

Gambar 2. Algoritma Desentisisasi Obat ${ }^{(2)}$

Cara pemberian obat dapat melalui oral maupun intravena, keduanya sama efektif namun pemberian melalui oral lebih aman dibandingkan dengan intravena dan lebih mudah untuk dilakukan serta tidak mahal. Terdapat beberapa protokol yang menggabungkan jalur oral dan parenteral, termasuk protokol untuk penisilin, insulin, 
agen kemoterapi, dan antibodi monoklonal. (9)

Dosis obat dapat dimulai dengan konsentrasi 1:1.000.000 sampai 1:100 dari dosis terapeutik, tergantung dari keparahan reaksi alergi yang pernah terjadi pada pasien atau bergantung pada titik akhir konsentrasi non iritatif uji kulit intradermal. Pada pasien dengan reaksi anafilaksis yang parah seperti hipotensi dan hilang kesadaran atau bronkospasme, dosis inisial harus dimulai dengan konsentrasi 1:1.000.000 sampai dengan 1:10.000 dari dosis terapeutik. Pada pasien dengan tes kulit positif terhadap konsentrasi obat non-iritatif, dosis awal dapat ditentukan berdasarkan titik akhir titrasi. Titrasi pada titik akhir hanya dapat digunakan pada pasien dengan uji kulit positif yang dilakukan sesuai dengan panduan dan menggunakan konsentrasi yang sudah ditetapkan. Pasien dengan reaksi alergi yang parah, protokol desensitisasi dapat diubah dengan cara menurunkan dosis awal, mengurangi kecepatan aliran infus, menambah interval pada pemberian dosis per oral, dan atau menambah jumlah tahapan pemberian obat. (2)

Dosis obat dinaikkan dua kali dosis awal setiap 15-30 menit untuk reaksi tipe cepat atau dengan interval sampai dengan 24 jam untuk reaksi tipe lambat. Pasien harus mematuhi jadwal pemberian obat setiap harinya untuk menjaga keadaan toleransi, kecuali timbul breakthrough reactions dimana peningkatan obat harus dihentikan atau diberikan dengan interval yang lebih lama. Terdapat beberapa protokol yang menaikkan dosis 10 kali lipat, meski lebih banyak menimbulkan efek samping. Farmakokinetik dan farmakodinamik obat harus dipertimbangkan untuk menentukan interval waktu pemberian dosis dan juga untuk mencegah kelebihan dosis. Morales dkk membuktikan desensitisasi obat bergantung pada dosis dan waktu. Jika waktu pemberian dosis berbeda maka terdapat perbedaan bermakna pada pelepasan mediator. Keadaan toleransi dapat terjadi lambat kalau dosis awal yang diberikan terlalu tinggi dan interval pemberian dosis terlalu cepat. Hal ini dapat menjelaskan reaksi breaktrough selama proses desensitisasi. Pada prosedur desensitisasi obat diperlukan jarak tertentu dalam pemberian dosis supaya didapatkan toleransi maksimum dari dosis terapeutik. (2)

Premedikasi dengan kortikosteroid sistemik atau antihistamin harus dihindari. Sampai saat ini masih belum jelas bagaimana pemberian antihistamin dapat menggangu proses desensitisasi cepat. Obat untuk penyakit penyerta harus diteruskan kecuali obat tersebut mengganggu proses desensitisasi. Obat beta blocker harus dihentikan 24 jam sebelum proses desensitisasi dimulai. Pada desensitisasi untuk reaksi tipe lambat diperlukan monitoring pemeriksaan darah rutin, dan enzim hati. (2)

Desensitisasi dikatakan sukses jika pasien dapat menyelesaikan sampai dengan dosis terapeutik dan dapat mentoleransi pemberian dosis berulang sampai pengobatan selesai. Efek samping yang sering terjadi adalah flushing, pruritus, eritema, dan urtikaria. Efek samping ringan sampai sedang dilaporkan pada $30-80 \%$ kasus alergi penisilin yang menjalani desensitisasi. Untuk menghindari desensitisasi berulang, dokter harus mempertimbangkan penatalaksanaan lanjutan pada reaksi ringan-sedang yang muncul dan melanjutkan prosedur. (1), (2) 


\section{De sensitisasi Penisilin}

Alergi penisilin merupakan alergi obat yang paling sering terjadi. Uji kulit digunakan untuk menegakkan diagnosis alergi. Reagen uji kulit sudah dikembangkan sejak tahun 1960 imunohistokimia penisilin sudah semakin jelas. Penisilin pecah menjadi senyawa antara atau disebut dengan hapten yang dapat menimbulkan reaksi imun. Uji kulit penting dilakukan sebelum melakukan desensitisasi penisilin. Jika hasil uji kulit negatif maka desensitisasi tidak perlu dilakukan. Nilai negative predictive value uji kulit terhadap determinan mayor dan minor mencapai $100 \%$. Jika hasil uji kulit positif terhadap determinan penisilin minor atau mayor maka semua antibiotik yang memiliki cincin b-laktam harus dihindari, yaitu penisilin, amoxicillin, ampicillin, dan sefalosporin. Pada kasus dengan hasil uji kulit negatif dapat dilakukan graded challange. Awalnya diberikan dosis 1:100, jika tidak terjadi reaksi selama pemantauan singkat maka dapat langsung diberikan dosis terapeutik penuh. Apabila terjadi reaksi alergi selama graded challange, maka penisilin hanya boleh diberikan dengan cara desensitisasi cepat. (1), (9)

Pada protokol desensitisasi yang didahului uji kulit, dosis awal ditentukan berdasarkan jumlah penisilin yang dapat ditoleransi selama uji tersebut. Jumlah yang dapat ditoleransi biasanya diartikan dengan konsentrasi 1:10.000 dari dosis terapeutik. Dosis selanjutnya digandakan setiap 15 menit sampai dosis terapeutik tercapai. Efek samping ringan selama prosedur pernah dilaporkan, namun efek samping yang fatal atau mengancam jiwa belum pernah dilaporkan. Jika timbul efek samping ringan maka harus diobati. Apabila reaksi tidak bertambah parah maka dosis penisilin dapat ditingkatkan. Setelah 30 menit dosis terapeutik tercapai, obat dapat diberikan melalui cara yang diinginkan. ${ }^{(9)}$ Contoh desensitisasi penisilin dapat dilihat pada tabel 1 dan 2. ${ }^{(1)}$

Tabel 1. Contoh desensitisasi penisilin dengan cara pemberian per oral ${ }^{(1)}$

\begin{tabular}{ccccc}
\hline Langkah & $\begin{array}{c}\text { Penisilin } \\
(\mathbf{m g} / \mathbf{m l})\end{array}$ & $\begin{array}{c}\text { Jumlah } \\
(\mathbf{m l})\end{array}$ & $\begin{array}{c}\text { Dosis } \\
(\mathbf{m g})\end{array}$ & $\begin{array}{c}\text { Dosis } \\
\text { kumulatif } \\
(\mathbf{m g})\end{array}$ \\
\hline 1 & 0,5 & 0,1 & 0,05 & 0,05 \\
2 & 0,5 & 0,2 & 0,1 & 0,15 \\
3 & 0,5 & 0,4 & 0,2 & 0,35 \\
4 & 0,5 & 0,8 & 0,4 & 0,75 \\
5 & 0,5 & 1,6 & 0,8 & 1,55 \\
6 & 0,5 & 3,2 & 1,6 & 3,15 \\
7 & 0,5 & 6,4 & 3,2 & 6,35 \\
8 & 5,0 & 1,2 & 6,0 & 12,35 \\
9 & 5,0 & 2,4 & 12,0 & 24,35 \\
10 & 5,0 & 5,0 & 25,0 & 49,35 \\
11 & 50,0 & 1,0 & 50,0 & 100,0 \\
12 & 50,0 & 2,0 & 100,0 & 200,0 \\
13 & 50,0 & 4,0 & 200,0 & 400,0 \\
14 & 50,0 & 8,0 & 400,0 & 800,0 \\
\hline
\end{tabular}

Tabel 2. Contoh desensitisasi penisilin dengan cara pembe rian intravena ${ }^{(1)}$

\begin{tabular}{ccccc}
\hline Langkah & $\begin{array}{c}\text { Penisilin } \\
(\mathbf{m g} / \mathbf{m l})\end{array}$ & $\begin{array}{c}\text { Kecepatan } \\
(\mathbf{m} / \mathbf{j a m})\end{array}$ & $\begin{array}{c}\text { Dosis } \\
(\mathbf{m g})\end{array}$ & $\begin{array}{c}\text { Dosis } \\
\text { kumulatif } \\
(\mathbf{m g})\end{array}$ \\
\hline 1 & 0,01 & 6 & 0,015 & 0,015 \\
2 & 0,01 & 12 & 0,03 & 0,045 \\
3 & 0,01 & 24 & 0,06 & 0,105 \\
4 & 0,01 & 50 & 0,125 & 0,23 \\
5 & 0,1 & 10 & 0,25 & 0,48 \\
6 & 0,1 & 20 & 0,5 & 1,0 \\
7 & 0,1 & 40 & 1,0 & 2,0 \\
8 & 0,1 & 80 & 2,0 & 4,0 \\
9 & 0,1 & 160 & 4,0 & 8,0 \\
10 & 10,0 & 3 & 7,5 & 15,0 \\
11 & 10,0 & 6 & 15,0 & 30,0 \\
12 & 10,0 & 12 & 30,0 & 60,0 \\
13 & 10,0 & 25 & 62,5 & 123,0 \\
14 & 10,0 & 50 & 125,0 & 250,0 \\
15 & 10,0 & 100 & 250,0 & 500,0 \\
16 & 10,0 & 200 & 500,0 & 1000,0 \\
\hline
\end{tabular}

\section{Desensitisasi Antibiotik Non-penisilin}

Antibiotik non-penisilin merupakan senyawa inert, oleh karena itu harus melalui proses metabolisme dan berikatan dengan protein pejamu untuk menjadi senyawa 
antara yang aktif. Sayangnya determinan imunogenik yang dihasilkan oleh proses metabolisme tersebut masih belum diketahui. Kekurangan ini menghambat berkembang-nya reagen uji kulit untuk $\operatorname{IgE}$ spesifik antibiotik non-penisilin. Oleh sebab itu, lebih sulit untuk menentukan pasien yang memiliki alergi tipe cepat terhadap antibiotik non-penisilin dan yang membutuhkan desensitisasi cepat. ${ }^{(9)}$

Penentuan perlu atau tidaknya dilakukan desensitisasi antibiotik nonpenisilin ditentukan berdasarkan riwayat dan uji kulit terhadap antibiotik dengan konsentrasi non-iritatif. Uji kulit dengan antibiotik naif dapat memberikan informasi yang cukup bermanfaat dan dapat memberikan titik awal desensitisasi karena jumlah obat yang ditoleransi selama uji kulit. Respons positif pada uji kulit menggunakan konsentrasi obat yang tidak mengiritasi memberikan kesan adanya antibodi IgE spesifik obat. Meskipun demikian respons negatif tidak menyingkirkan reaksi alergi tipe cepat karena uji tersebut tidak mengikut-sertakan semua determinan alergenik yang relevan. Empedrad dkk secara sistematis menentukan konsentrasi non iritatting beberapa antibiotik yang biasa digunakan (Tabel 3). ${ }^{(2)}$, (9)

Tabel 3. Konsentrasi non-iritatif uji kulit intrade rmal bebe rapa antibiotik ${ }^{(2)}$

\begin{tabular}{lcl}
\hline Antibiotik & $\begin{array}{c}\text { Konsentrasi } \\
\text { penuh } \\
(\mathbf{m g} / \mathbf{m L})\end{array}$ & $\begin{array}{c}\text { Konsenstrasi } \\
\text { non-iritatif }\end{array}$ \\
\hline Cefotaxime & 100 & $10 \mathrm{kali}$ \\
Cefazolin & 330 & $10 \mathrm{kali}$ \\
Ceftazidime & 100 & $10 \mathrm{kali}$ \\
Ceftriaxone & 100 & $10 \mathrm{kali}$ \\
Klindamisin & 150 & $10 \mathrm{kali}$ \\
Eritromisin & 50 & $1000 \mathrm{kali}$ \\
Azitromisin & 100 & $10.000 \mathrm{kali}$ \\
\hline
\end{tabular}

Jika uji kulit menggunakan konsentrasi non-iritating memberikan hasil negatif, maka antibiotik harus diberikan dengan cara desensitisasi atau graded challange bergantung pada keparahan reaksi alergi dan waktu sejak sejak reaksi alergi terakhir. Jika pasien melaporkan ruam gatal tanpa gejala lain di hari pertama pasien minum antibiotik sulfa dan terjadi 20 tahun yang lalu, maka dapat dilakukan graded challange. Sebaliknya jika ada riwayat anafilaksis maka harus dilakukan desensitisasi. Jika dokter tidak yakin dengan tipe reaksi sebelumnya, maka desensitisasi harus dilakukan. Prinsip desensitisasi penisilin dapat diaplikasikan pada antibiotik non-penisilin. (9)

\section{De sensitisasi Aspirin dan NSAID}

Beberapa reaksi pseudoalergi dan alergi disebabkan oleh aspirin dan nonsteroidal anti-inflamatory drugs (NSAIDs) telah dilaporkan sejak sintesis pertama asam asetilsalisilat pada tahun 1897. (13) Hipersensitivitas asam asetilsalisilat (ASA) berkisar antara 0,6-2,5\% dan pada dewasa dengan asma berkisar antara 4,3-11\%. Hipersensitivitas terhadap ASA diawali dengan rinitis pada tiga dekade pertama, lebih sering didahului oleh infeksi virus yang ditandai dengan kongesti nasal, hiposmia, rinorea kronik, dan polip nasal. Pada akhirnya akan muncul aspirin induced athsma (AIA), 20\% asma ringan, 30\% sedang, 50\% berat dan kronik serta bergantung pada kortikosteroid. Selain asma dan rinitis dapat juga muncul urtikaria, angioedema, dan anafilaksis. (14)

Desensitisasi terhadap aspirin dipertimbangkan untuk pasien jantung dan pasien hamil dengan sindrom antiofolipid serta merupakan hal yang umum dilakukan pada pasien dengan aspirin-exacerbated respiratory disease (AERD). Desensitisasi aspirin efektif pada kasus urtikaria, angioedema, dan reaksi anafilaksis yang diinduksi obat, sebaliknya desensitisasi tidak efektif jika reaksi tersebut muncul pada pasien dengan urtikaria kronis idiopatik. (15) 
Contoh protokol desensitisasi aspirin dapat dilihat pada tabel 4. (4)

Tabel 4 Contoh protok ol desensitisasi aspirin ${ }^{(4)}$

\begin{tabular}{cc}
\hline Waktu (menit) & Dosis (mg) \\
\hline 0 & 0,31 \\
20 & 0,3 \\
40 & 1 \\
60 & 3 \\
80 & 10 \\
100 & 30 \\
120 & 40 \\
140 & 81 \\
160 & 162 \\
\hline
\end{tabular}

\section{SIMPULAN}

Desentisisasi obat merupakan tatalaksana alergi obat bila obat tersangka tidak tergantikan. Sebelum memulai prosedur desensitisasi dokter harus menelaah risiko dan keuntungan tindakan tersebut.

\section{UCAPAN TERIMAKASIH}

Terima kasih kepada dr. Raveinal, Sp.PD-KAI, FINASIM yang telah memberikan bimbingan dalam menyelesaikan jurnal ini. Semoga amalan dan kebaikan beliau mendapat balasan dari Allah SWT.

\section{DAFTAR PUSTAKA}

1. Liu A, Fanning L, Chong H, Fernandez J, Sloane D, Sancho-Serra M, Castells M. Desensitization regimens for drug allergy: state of the art in the 21st century. Clinical \& Experimental Allergy.2011;41:1679-89.

2. Cernadas JR, Brockow K, Romano A, et al. General Consideration on rapid desensitization for drug hypersensitivity - a consensus treatment. Allergy. 2010:65;1357-66

3. Brockow K, Przybilla B, Aberer W, Bircher AJ, Brehler R, Dickel H, et al. Guideline for the diagnosis of drug hypersensitivity reactions. Allergo J Int. 2015;24:94-105.
4. Solensky S. Drug Hypersensitivity. Med Clin N Am. 2006; 90: 233-260.

5. Johanson SG, Bieber T, Dahl R, et al. Revised nomenclature for allergy for global use. Report of the Nomenclature Review Comitee of The World Organization, October 2003. J Allergy Clin Immunol. 2004;113:832-36

6. Stites D. P., Terr A. I., Parslow T. G., 1994. Allergy Desensitization. Basic and Clinical Immunology. Eight Edition. Sanfransisco: Lange Medical Book. Prentice Hall International Inc. Pp: 739-43

7. Stites D. P., Stobo J. D., 1976. Basic and Clinical Immunology. Sixth Edition. Lange Medical Book. Prentice Hall International Inc. Pp: 432-3.

8. Gruchalla RS. Drug Allergy. J Allergy Clin Immunol. 2003;111:548-59

9. Sullivan TJ. Protocol for rapid and slow sentization. Georgia. 2009: 1-40.

10. Solensky R. Drug Desensitization. Immunol Allergy Clin $\mathrm{N}$ Am. 2004;24:425- 443

11. Sharma VK, Asati DP, Khandpur S, Khilnani GC, Kapil A. Study of sepsis in dermatology ward: A preliminary report. Indian J Dermatol Venereol Leprol. 2007;367:1-5

12. Sánchez LV, Alenazy LA, GarciaNeuer M, Castells MC. Drug Hypersensitivity and Desensitizations : Mechanisms and New Approaches. Int. J. Mol. Sci. 2017 ;18 (1316) : 1-17.

13. Castells M. Desensitization for drug allergy. Curr Opin Allergy Clin Immunol 2006;6:476-481.

14. Chopra N, Oppenheimer J, Derimanov GS, Fine PL. Vancomycin anaphylaxis and successful desensitization in a patient with end stage renal disease on hemodialysis by maintaining steady antibiotic levels. Ann Allergy Asthma Immunol 2000;84:633-5. 
15. Gorman SK, Zed PJ, Dhingra VK, Ronco JJ. Rapid imipenem/cilastatin desensitization for multidrug-resistant Acinetobacter pneumonia. Ann Pharmacother 2003;37:513- 6 . 